\title{
The Exponential Smoothing Methods (Double-Triple) and Its Applications On Time Series Data
}

\author{
Pratikno, B ${ }^{1}$, Niqatani, B.D. ${ }^{2}$, Hasan, M. ${ }^{3}$, and Erfiana, D. ${ }^{4}$ \\ 1,2,3,4) Department of Mathematics \\ Faculty of Mathematics and Natural Science \\ Jenderal Soedirman University, Purwokerto, Indonesia. \\ ${ }^{1}$ bpratikto@gmail.com \\ ${ }^{2}$ niqatani.belsa@gmail.com \\ ${ }^{3}$ miftachulhasan07@gmail.com \\ 4dinaerfiana6@gmail.com
}

\begin{abstract}
The research studied double and triple exponential smoothing methods and its applications on forecasting time series data. Due to the original of plot data (pattern) increasing seasonal, the exponential smoothing method and mean absolute percentage error (MAPE) are then used. Here, Zaitun and Minitab software are used to compute the result of the forecasting. The result showed that the smoothing parameters significant influenced the significant result of the forecasting with small MAPE around 0.09 and 0.1, in double smoothing exponential (DES) and triple smoothing exponential (TES), respectively.
\end{abstract}

Keyword: Forecasting, parameters lag and smoothing exponential.

\section{INTRODUCTION}

Many authors have already studied some techniques of the forecasting, such as Najmudin [11], Salvatore [18], Nasution and Prasetyawan [12], and Indiyanto [6]. Furthermore, detail and in depth statistical methods for forecasting on time series data analysis is found in Abraham and Ledolter [1]. They expressed that time series tend to exhibit a cyclical pattern that has tendency to repeat itself on a fixed period. In term of exponential smoothing methods, we noted some authors studied it on time series analysis data, such as Oktaviarina [14], Montgomery [9], Chase and Jacobs [4], Aritonang [3], Oktaviana and Wijaya [15], Pangestu et al. [16], and Stevenson and Sum [19].

Following Makridakis [7] there are three methods of the exponential smoothing, namely (1) single exponential smoothing (for random and stationary data), (2) double exponential smoothing (Brown and Holt methods). It tends to be suitable for trend increases, and (3) triple exponential smoothing (for seasonal of the trend). In the triple exponential smoothing (TES), there are three smoothing weighted, namely $\alpha, \beta$ and $\gamma$ (Makridakis, et al., [8]). More detail with TES, single exponential smoothing (SES), and double exponential smoothing (DES) are found in Makridakis [7].

To measure the significant result of the forecasting for $p$ period ahead, there are three measurements of error, namely (1) mean absolute deviation (MAD), (2) mean absolute percentage error (MAPE), and (3) mean squared error (MSE) (see Najmudin, [11]). Due to the values of MAPE is smaller than MAD and MSE, we then used it. Note that the formula of MAPE is given

$$
M A P E=\frac{1}{n} \sum_{t=1}^{n} \frac{\left|Y_{t}-\hat{Y}\right|}{Y_{t}},
$$

where $Y_{t}$ is an actual data at period $t, \hat{Y}_{t}$ is a forecasting data at period $t$, and $n$ is a number of data. Following Goh and Law [5], and Andini [2], the criteria of MAPE is noted as: (1) $0<x<10$ is very good, (2) $10 \leq x<20$ is good, (3) $20 \leq x<50$ is enough, (4) $x \geq 50$ is bad. We note here that the small value of MAPE is then chosen as a best indicator in determining the significant forecast.

There are several steps to produce the significant result of the forecasting on $p$ period ahead: (1) plot and identify the trend of the data (time series data), (2) find the suitable method, (3) give a simulation data, (4) used the formula and software to find the result of the forecasting, and (5) check the significant result using MAPE.

In this paper, the introduction is given in Section 1. The double exponential smoothing (DES) and its simulation are presented in Section 2. The triple exponential smoothing (TES) and its simulation are obtained in Section 3. Then, Section 4 described the conclusion of the research. 


\subsection{The Double Exponential Smoothing Method}

Following Makridakis [7] and Makridakis, et al., [8], the DES had multiple smoothing weighted, namely $\alpha, \gamma, a_{t}$ and $b_{t}$. The $\alpha$ and $\gamma$ are chosen at the smallest values of MAPE (in several trials). Detail of the DES is found in Makridakis [7]. To make clear the concept of DES and TES, we refer to the first theory of smoothing exponential methods, that is the SES. Here, the formula of SES is given as

$$
\hat{Y}_{t+1}=\alpha Y_{t}+(1-\alpha) \hat{Y}_{t}
$$

where $Y_{t}$ is an actual data at period $t, \quad \hat{Y}_{t}$ is a forecasting data period $t, n$ is a number of data, $\hat{Y}_{t+1}$ is the forecasting data period $t+1$, and $\alpha=\left(\frac{1}{n}\right)$ is the parameter smoothing $(0<\alpha<1)$. Furthermore, following Najmudin [11], the DES's formula is then presented in term of the Brown is given as

$$
\hat{Y}_{t+p}=a_{t}+b_{t} p
$$

where $\hat{Y}_{t+p}$ is a forecasting data on $p$ period of $t, a_{t}$ is a differences values of smoothing at $t$ period, $b_{t}$ is a additional factor at period of $t, p$ is a number of period ahead to forecast. To get the $\hat{Y}_{t+p}$, we must follow some steps: (1) compute the smoothing exponential using $L_{t}=\alpha Y_{t}+(1-\alpha) L_{t-1}$, (2) then we calculate double smoothing exponential with $L_{t}^{*}=\alpha Y_{t}+(1-\alpha) L_{t-1}^{*}$, (3) determine $a_{t}$ using $a_{t}=2 L_{t}-L_{t}^{*}$, (4) and $b_{t}$ is determined using $b_{t}=\frac{\alpha}{1-\alpha}\left(L_{t}-L_{t}^{*}\right)$. Here, $L_{t}$ is an estimation value of single smoothing and $L_{t}^{*}$ is an estimation value of double smoothing. Similarly, Following Najmudin [11], Holt method follows three steps, that are: (1) determine level of estimation using $L_{t}=\alpha Y_{t}+(1-\alpha)\left(L_{t-1}+T_{t-1}\right)$, (2) we also determine trend of estimation using $T_{t}=\gamma\left(L_{t}-T_{t-1}\right)+(1-\gamma)\left(T_{t-1}\right)$, and furthermore, we written the Holt formula as

$$
\hat{Y}_{t+p}=L_{t}+p T_{t}
$$

where $\hat{Y}_{t+p}$ is a forecasting data on $p$ period of $t, a_{t}$ is a differences values of smoothing at $t$ period, $b_{t}$ is a additional factor at period of $t, p$ is a number of period ahead to forecast, $L_{t}$ is a level estimation, and $T_{t}$ is a trend estimation. Note that $L_{0}$ and $T_{0}$ are intercept of linear estimation and slope, respectively (Montgomery [10]).

A simulation study is given for forecasting data of a number of motorcycle in Figure 1. Figure 1 showed that the trend of the plot of the data increases as the month increases (Year of data: 2017-2018).

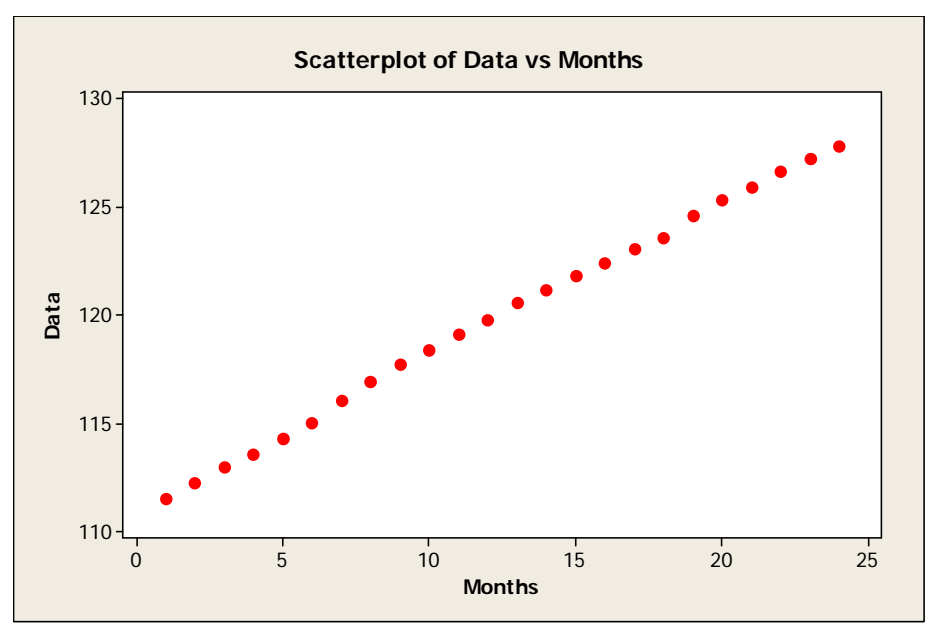

Figure 1. Trend of motorcycle data 
It is clear that the data (Figure 1.) increases as the month increase (has a trend). We therefore decide to use DES as a suitable method. From the simulation of MAPE (smallest MAPE $=0.09$ ), we got $\alpha=0.7$ for Brown method, and $\alpha=0.9$ and $\gamma=0.1$ for Holt. The forecasting data is then given in Table 1 and Table 2 for both methods (Brown and Holt).

Table 1. The Forecasting data and Its error (Brown)

\begin{tabular}{|l|l|l|l|}
\hline Months (2019) & $\hat{Y}_{t+p}$ & $Y$ & Error (\%) \\
\hline January & $128.4 \times 10^{3}$ & $128.5 \times 10^{3}$ & 0.08 \\
\hline February & $129.1 \times 10^{3}$ & $129.14 \times 10^{3}$ & 0,07 \\
\hline March & $129.7 \times 10^{3}$ & $129.68 \times 10^{3}$ & 0,02 \\
\hline
\end{tabular}

Table 2. The Forecasting data and Its error (Holt)

\begin{tabular}{|l|l|l|l|}
\hline Months (2019) & $\hat{Y}_{t+p}$ & $Y$ & Error (\%) \\
\hline Januari & $128.5 \times 10^{3}$ & $128.55 \times 10^{3}$ & 0,01 \\
\hline Februari & $129.2 \times 10^{3}$ & $129.1 \times 10^{3}$ & 0,06 \\
\hline Maret & $129.9 \times 10^{3}$ & $129.7 \times 10^{3}$ & 0,17 \\
\hline
\end{tabular}

From Table 1 and 2., we see that the average of error the Brown method is 0.04 and the average of error of the Holt is 0.19 . We then conclude that Brown method is better than Holt (the error $0.04<0.19$ ).

\subsection{The Triple Exponential Smoothing Method}

Similarly with the Section 2, we then studied the TES in this section. Following Makridakis [7] and Makridakis, et al., [8], the triple exponential smoothing (TES) had three smoothing weighted, namely $\alpha, \beta$ and $\gamma$. These parameters are chosen based on the smallest mean absolute percentage error (MAPE) on several trials. Detail TES is found in Makridakis [7]. Following Makridakis et al. [8] and Najmudin [11], the general formula of the TES is given as

Level

$$
L_{t}=\alpha\left(Y_{t}-S_{t-s}\right)+(1-\alpha)\left(L_{t-1}-T_{t-1}\right)
$$

Trend

$$
\begin{array}{ll}
: & L_{t}=\alpha\left(Y_{t}-S_{t-s}\right)+(1-\alpha)\left(L_{t-1}-1\right. \\
& T_{t}=\gamma\left(L_{t}-L_{t-1}\right)+(1-\gamma)\left(T_{t-1}\right)
\end{array}
$$

Seasonal

$$
S_{t}=\beta\left(Y_{t}-L_{t}\right)+(1-\beta)\left(S_{t-s}\right)
$$

Forecasting : $\quad \hat{Y}_{t+p}=L_{t}+p T_{t}+S_{t-s+p}$

where $L_{t}$ is value of level, $\alpha, \beta$ and $\gamma$ are and smoothing weighted, $T_{t}$ is an estimation trend, $\gamma$ is smoothing constant of trend estimation, $S_{t}$ is an estimation of seasonal, $\beta$ is smoothing constant of trend seasonal, $S$ is length of seasonal, $\hat{Y}_{t+p}$ is a forecasting data on $p$ period ahead, and $p$ is period of forecasting.

A simulation study is given to the data of the executive class train ticket as below. The scatter plot is presented in Figure 2. ( Niqatani [13] and Pratikno et al. [17]), we then chose the TES as a suitable method for this plot. 


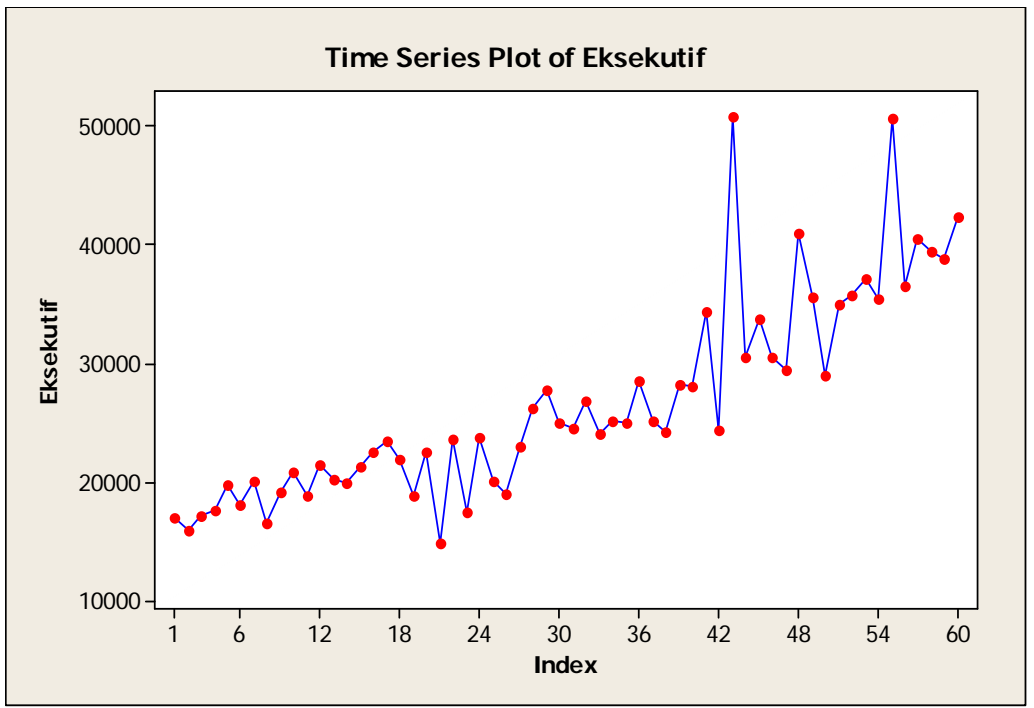

Figure 2. Scatter plot of the executive class train ticketing

From Figure 2., we see that the trend of the plot increases (seasonal). Therefore, we choose the TES as a suitable method for forecasting it. The first procedure, we firstly choose the values of $\alpha, \beta$, and $\gamma$ from the smallest MAPE that generate using Zaitun software. Here, we got the parameters smoothing $\alpha=0.1$, $\beta=0.6$, and $\gamma=0.1$ on MAPE $=0.1$ (as smallest MAPE). Using these parameters ( $\alpha=0.1, \beta=0.6$, and $\gamma=0.1$ ), and following Pratikno, et al. [17], we then get the values of the data forecasting (Figure 3.).

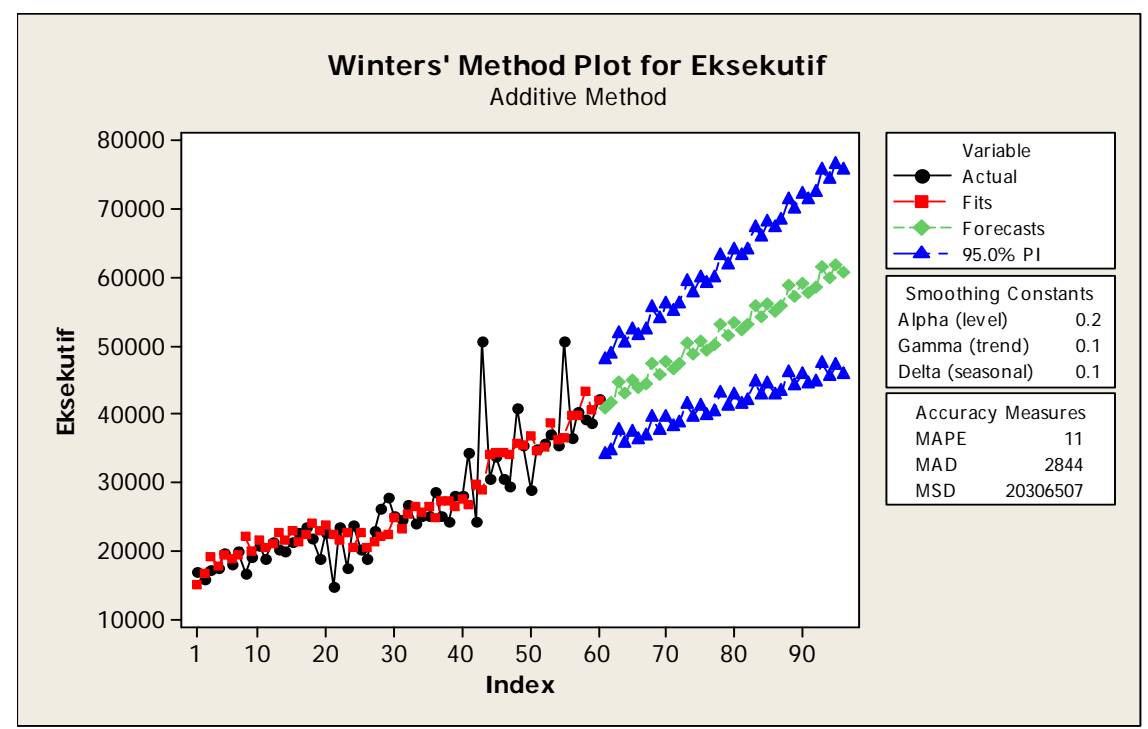

Figure 3. The forecasting of executive class train ticketing

From Figure 3. It is clear that the green line (forecasting) is in line with the trend of the actual data (red line). They both lie at $95 \%$ its confidence interval, with the accuracy measurement of the MAPE is 0.1 (small). The actual error is given in Table 3 .

Table 3. The values of the forecasting data on January-March 2018

\begin{tabular}{|l|lcc|}
\hline Year 2019 & January & February & March \\
\hline$Y_{t}$ & 39960 & 30678 & 32378 \\
\hline$\ddot{Y}_{\boldsymbol{z}+\boldsymbol{p}}$ & 36652 & 38364 & 40947 \\
\hline \multicolumn{1}{|c|}{ error } & 0.006 & 0.02 & 0.2 \\
\hline
\end{tabular}

From Table 3. we see that the error of the forecasting is around $0.006-0.2$ (in average is 0.07 ). It means that the error is relative small. Thus, we conclude that it is an enough error for getting the good forecasting. 


\section{CONCLUSION}

The research studied the double and triple smoothing exponential method in forecasting time series data. Both methods are suitable due to the trend of the plot increases (DES methods) and seasonal increases (TES). The MAPE is used to obtain the eligible forecasting. Zaitun and Minitab software are used to compute the result. The result showed that the forecasting data are really influenced by smoothing parameters, with the smallest MAPE are 0.09 (DES) and 0.1 (TES), respectively. For the DES, Brown method is better than Holt method.

\section{ACKNOWLEDGMENT}

I thankfully to the colleague for providing me the data

\section{REFERENCES}

[1] B. Abraham and J. Ledolter. Statistical Methods for Forecasting. John Wiley and Sons, Inc, 2005.

[2] T.D. Andini and P. Auristandi. Peramalan Jumlah Stok Alat Tulis Kantor di UD Achmad Jaya Menggunakan Metode Double Exponential Smoothing, 10(01), 1-10, 2016.

[3] R.L. Aritonang. Peramalan Bisnis. Jakarta: Ghalia Indonesia, 2002

[4] R. Chase and R. Jacobs. Operation and Supply Chain Management. Global Case Edition, New York: Mc Graw Hill, 2014.

[5] C. Goh dan R. Law. Modeling and Forecasting Tourism Demand for Arrivals with Stochastic Nonstationary Seasonality and Intervention. Tourism Management. 23: 499-510, 2002.

[6] R. Indiyanto. Perencanaan dan Pengendalian Produksi. Surabaya: Yayasan Humaniora, 2008.

[7] S. Makridakis, S.C.Wheelwright, and V.E, McGee. Metode dan Aplikasi Peramalan. $2^{\text {nd }}$ edition. Jakarta: Erlangga, 1992.

[8] S. Makridakis, S.C.Wheelwright, and V.E, McGee. Metode dan Aplikasi Peramalan. $2^{\text {nd }}$ edition edua. Jilid Satu. Jakarta: Erlangga, 1999.

[9] D. Montgomery. Forecasting and Time Series Analysis. New Jersey: Jhon Wiley dan Sons.Inc, 2008.

[10] D. Montgomery. Forecasting and Time Series Analysis. New Jersey: Jhon Wiley dan Sons.Inc, 1999

[11] Najmudin. Teknik Peramalan Bisnis dengan Minitab. Purwokerto: Universitas Jenderal Soedirman, 2012.

[12] A.H. Nasution and Y. Prasetyawan. Perencanaan Pengendalian Produksi $1^{\text {st }}$ edition. Yogyakarta: Penerbit Graha Ilmu, 2008.

[13] B.D. Niqatani. Laporan Kerja Praktek. Unpublished, 2018.

[14] A. Oktaviarina.Peramalan Jumlah Penumpang Kereta Api di Indonesia Dengan Menggunakan Metode Exponential Smoothing. Jurnal Buana Matematika Vol 7, No 2, 2017.

[15] B. Oktaviana and H.S. Wijaya. Urgensi Pengendalian Kendaraan Bermotor Di Indonesia. Jurnal Rekayasa Teknik Sipil Universitas Madura. Vol. 2 No. 1. ISSN 2527-5542, 2017.

[16] F. Pangestu, A.W. Widodo and B. Rahayudi. Prediksi Jumlah Kendaraan Bermotor di Indonesia Menggunakan Metode AverageBased Fuzzy Time Series Models. Jurnal Pengembangan Teknologi Informasi dan Ilmu Komputer. Vol. 2 No. 9. 2923-2929. ISSN 2548-964X, 2018.

[17] B. Pratikno, D. Erfiana, Mashuri and B.D. Niqatani. The Exponential Smoothing Method and Its Forecasting. International Conference. SICoMAS2019/UNSOED Purwokerto, 2019.

[18] D. Salvatore. International Economics. $4^{\text {th }}$ edition. MacMillan Publishing Company, 1993.

[19] W.J. Stevenson, and C.C. Sum. Manajemen Operasi Perspektif Asia. $9^{\text {th }}$ edition. Jakarta: Salemba Empat, 2014. 